\title{
Knowledge, Attitudes and Behaviors about Hand Hygiene among Students Training in Health Departments of Two Universities
}

\author{
Gülay Yılmazel $^{1}$ (iD , Nursel Üstündağ Öcal ${ }^{2}$ (DD , Çiğdem Kader $^{3}$ (iD
}

${ }^{1}$ Hitit Üniversitesi,Sağlık Bilimleri Fakültesi, Çorum/Türkiye

${ }^{2}$ Yozgat Bozok Üniversitesi, Sağlık Hizmetleri Meslek Yüksekokulu, Yozgat/Türkiye

${ }^{3}$ Yozgat Bozok Üniversitesi, Tıp Fakültesi Enfeksiyon Hastalıkları ve Klinik Mikrobiyoloji Ana Bilim Dalı, Yozgat/Türkiye

Gülay YILMAZEL

Nursel ÜSTÜNDAĞ ÖCAL

Çiğdem KADER

Correspondence: Nursel Üstündağ Öcal Yozgat Bozok Üniversitesi, Sağlık Hizmetleri Meslek Yüksekokulu, Yozgat/Türkiye

Phone: +903542421034

E-mail: nursel.ustundagocal@yobu.edu.tr

Received

\section{ABSTRACT}

Objective: The aim of this study was to evaluate the knowledge, attitudes and behaviors about hand hygiene among students training in health departments of two universities.

Methods: This descriptive study was conducted between January-February 2018. A total of 480 students training in nursing and elderly care/anesthesia departments were included in the sampling. Data were analyzed by SPSS 17.0 package program with using percentage, mean, chi-square test. In analysis $p<0.05$ value was considered statistically significant.

Results: Of the study group, $71,2 \%$ were female, $65,6 \%$ were in nursing department and the mean age was $20,80 \pm 1,90$ years. In our study, 73,5\% of the students knew that dirty hands of health workers was the main road for crossing the harmful microorganisms and it was significantly higher in nursing department $(p<0.05)$. The knowledge of both practices was higher in nursing department than in elderly care/ anesthesia $(p<0.05)$. Only a quarter of all students knew that the minimum time required for alcohol-based handrubbing effects on microorganisms and it was significantly higher in nursing department $(p<0.05)$.

Conclusions: There was a big gap on hand hygiene knowledge, attitude and behaviors in both two departments. Gender and residence region were effective on hand hygiene behaviors.

Keywords: Hand hygiene, knowledge, attitudes, behaviors, university students

İki Üniversitenin Sağlık Bölümünde Öğrenim Gören Öğrencilerin El Hijyeni Hakkındaki Bilgi, Tutum ve Davranışları

Amaç: Bu çalışmanın amacı iki üniversitenin sağlık bölümlerinde eğitim gören, öğrencilerin el hijyeni konusundaki bilgi, tutum ve davranışlarını değerlendirmektir.

Yöntemler: Tanımlayıcı tipteki bu çalışma Ocak-Şubat 2018 tarihleri arasında yürütülmüştür. Hemşirelik, yaşlı bakımı ve anestezi bölümlerinde eğitim alan toplam 480 öğrenci çalışmaya dahil edilmiştir. Veriler SPSS 17.0 paket programı ile yüzde, ortalama, ki-kare testi kullanılarak analiz edildi. Analizlerde p \&lt;0.05 değeri istatistiksel olarak anlamlı kabul edildi.

Bulgular: Çalışma grubunun \%71,2'si kadın, \%65,6'sı hemşirelik bölümünde ve yaş ortalaması 20,80 $\pm 1,90$ yıldı. Çalışmamızda öğrencilerin \%73,5'i zararlı mikroorganizmaların bulaşında ana yolun sağlık çalışanlarının kirli ellerinin olduğunu bildi ve ve bu oran hemşirelik bölümünde anlamlı ölçüde yüksekti $(p<0.05)$. El hijyeni ile ilgili her iki uygulamaya ilişkin bilgi hemşirelik bölümünde yaşıı bakımı / anestezisine göre daha yüksekti $(p<0.05)$. Tüm öğrencilerin sadece dörtte biri alkol bazlı el dezenfektanı ile el ovma için gerekli minimum sürenin mikroorganizmalar üzerindeki etkilerini bildi ve bu oran hemşirelik bölümünde anlamlı̈ öçüde yüksekti $(p<0.05)$.

Sonuç: Her iki üniversitenin sağlıkla ilgili bölümlerindeki öğrencilerde el hijyeni bilgisi, tutumu ve davranışları açısından yetersizliklerin olduğu belirlendi. Cinsiyet ve yerleşim bölgesi el hijyeni davranışlarında etkili bulundu.

Anahtar Kelimeler: El hijyeni, bilgi, tutum, davranış, üniversite öğrencisi 
$\mathbf{P}$ atient safety is in the cornerstone of medical care in modern era. Health care-associated infection ( $\mathrm{HCAl}$ ) is a major problem for patient safety in worldwide. According to World Health Organization (WHO) estimates, more than 1,4 million patients are affected at any time, which has considerable impact on morbidity and mortality rates and financial burden for health systems (1).

In high-income countries, HCAl affects at least $7 \%$ of patients admitted to hospital and about $15 \%$ of those in lowincome and middle-income countries $(2,3)$.

According to a report covering European Centre for Disease Prevention and Control (ECDC), approximately $6 \%$ of patients suffer from health-related infections admitted to acute service hospitals in Europe. This rate varies between $2-10 \%$ in the member countries (4). In USA, on any given day, about one in 25 hospital patients has at least one healthcare-associated infection (5). Annual costs were estimated to be as $€ 7$ billion in Europe and US\$ 6,8 billion in the USA (2). Evidence of endemic HCAI in developing countries report hospitalwide rates higher than in developed countries (6-13).

One-day prevalence surveys have found HCAI prevalence as $19,1 \%$ in Albania (13), 17,8\% in Morocco (12), 17,9\% in Tunisia (11) and $14,8 \%$ in Tanzania (10) hospitals.

HCAl, in the world are considered as an important public health problem, and serious efforts are also being made to prevent and control in Turkey. A protocol is signed between The Ministry of Health and the World Health Organization (WHO) which aims at "zero infection" in health service in 2018 (14).

Hand hygiene is the most effective and a simple way by building block for pathogen transmission in the maintenance of health-care delivery (15-17). Compliance of health-care workers (HCW) to hand hygiene guidelines varies from country to country, but is remains under expectations to ensure patient safety $(1,18)$. On average, healthcare providers compliance to less than half of the times they should (5).

The aim of this study was to evaluate the knowledge, attitudes and behaviors about hand hygiene among students training in health departments of two universities.

\section{MATERIAL AND METHODS}

This descriptive study was conducted in 2018. The population of the study was consisted of Bozok University Vocational School of Health Service and Hitit University Faculty of Health Sciences students. Students attending elderly care/anestezi departments from Bozok University Vocational School of Health Service and nursing department from Hitit Universty Faculty of Health Sciences were included in the sampling $(n=480)$.

There were 365 nursing and 190 elderly care/ anesthesia students in these universities. The students who could not be met after three visits were excluded from the study. The questionnaires which were not completely filled were not taken for analysis. So study was completed with a total of 315 nursing and 165 elderly care/anesthesia students who filled the all questionnaire.

Data was collected through a questionnaire which was prepared in accordance with the literature review by the researchers. Knowledge, attitudes and practices related to hand washing were questioned as well as socio-demographic characteristics of students. The knowledge on hand hygiene was assessed using WHO hand hygiene questionnaire for HCW. It consists of 25 questions which had answers as "yes", "no", "true" and "false" (1).

The study was planned in accordance with the principles of Helsinki and was approved by Bozok University Clinical Research Ethics Committee (2017-KAEK-189_2018.04.11_09).

SPSS 17.0 package program was used to analyze the data. In analysis, percentage, mean, chi-square test were used. In evaluation $\mathrm{p}<0.05$ value was considered statistically significant.

\section{RESULTS}

Study was colmpleted with 480 students. Of the study group, $50,8 \%$ were $\geq 20$ years, $71,2 \%$ were female, $65,6 \%$ were

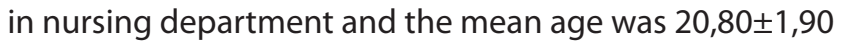
years. Among the students $45,2 \%$ were stated that their family were residing in the western/northern region of the country and among those 50,8\% were living in the city center continuously. The rate of students with nuclear family structure was $82,9 \%$, who stayed in dormitories was $61,9 \%$ and students with social security was $97,3 \%$. Majority of students $(90,4 \%)$ stated that hand hygiene course was given to the them in the first year. 
Comparison of knowledge on hand hygiene among students according to departments was given in Table 1.

About three out of every four students knew that dirty hands of health workers was the main road for crossing the harmful microorganisms among the patients in the health facility. The rate of those who knew the main transmission path of microorganisms was higher in nursing students than in elderly care and anesthesia students $(p<0.05)$.

Although the rate of knowledge about source of germs causing health care-related infections was low in both departments and there was no significant difference $(p>0.05)$.

Although $77,1 \%$ of the students were aware of the rapid effect of hand rubbing, this rate was higher in elderly care and anesthesia students $(p<0.05)$. The knowledge of both practices was higher in nursing students than in elderly care and anesthesia $(p<0.05)$.

Only a quarter of all students knew that the minimum time required for alcohol-based handrubbing effects on microorganisms. Knowledge about minimum time was significantly higher in nursing students $(p<0.05)$.

More than half of all students knew which hand hygiene method should be applied in which situations. This rate was significantly higher in nursing students $(p<0.05)$.

Almost all of the students in both departments were aware of situations which were should be avoided as associated with increased likelihood of colonisation of hands with harmful germs, there were no significant differences between the departments ( $p>0.05$ ).

Table 2 showed the comparison of hand hygiene attitudes and behaviors of students according to their departments.

In the study group, $88,0 \%$ were thought they applied hand hygiene during internships. This rate was $90,5 \%$ and $83,0 \%$ among nursing and elderly care/anesthesia departments respectively. The difference between the hand hygiene attitudes of the students according to departments was significant $(p<0.05)$.

The rate of those who who washed their hands 8-10 times in a day was $50 \%$ in the whole group. This rate was $56,5 \%$ in nursing department while it was $37,6 \%$ in elderly care/ anesthesia department. The frequency of handwashing was significantly different between the departments $(p<0.05)$. Almost all of the students used water and soap in handwashing, but there was no difference in the type of material for hand hygiene between departments ( $p>$ 0.05).

Hand hygiene behaviors according to the gender of the students were given in Table 3.

Daily handwashing frequency was significantly higher among females than males $(p<0.05)$. Almost all of the male and females were washing their hands with soap and water, there was a significant difference between the gender $(p<0.05)$. More than half of the female students stated that their dried hands with paper towels and it was significantly higher in females than males $(p<0.05)$.

Hand hygiene behaviors of students according to residence regions of their families were given in Table 4.

The frequency of handwashing and the rate of drying hands with paper towels were significantly higher among the students whose family residing in the western/northern region of the country $(p<0.05)$. There was no significant difference between the regions in terms of the type of material used in handwashing $(p>0.05)$.

\section{DISCUSSION}

Hand hygiene is very important in preventing hospital infections. Germs can be transmitted through the healthcare provider's dirty hands (19). There is a serious need for accurate information, positive attitude and proper practice in hand hygiene throughout basic trainings of all $\mathrm{HCWs}$, although it maintains its place in the agenda (20).

In this study, three-quarters of the students generally knew the main path in cross-transmission of harmful microorganisms in hospitals (Table 1). While this result was consistent with a Sri Lankan study (21) it was higher than an Indian study (22).

Regardless of department, in our study less than one-fifth of the students knew the source of microorganism responsible for HCAl ( $p>0.05)$. (Table 1). On the other hand, in two studies conducted in India, this rate has been reported to varied between $40-94 \%(22,23)$. 
Table 1. Comparison of knowledge on hand hygiene among students according to departments

\begin{tabular}{|c|c|c|c|c|}
\hline \multirow[t]{2}{*}{ Knowledge } & $\begin{array}{l}\text { Nursing } \\
(n=315)\end{array}$ & $\begin{array}{l}\text { Elderly care / } \\
\text { anesthesia } \\
(n=165)\end{array}$ & $\begin{array}{c}\text { Total } \\
(n=480)\end{array}$ & p \\
\hline & No.(\%) & No.(\%) & No.(\%) & \\
\hline $\begin{array}{l}\text { Q1.The main route of cross-transmission of potentially harmful germs } \\
\text { between patients in a health-care facility }\end{array}$ & $248(78,7)$ & $105(63,6)$ & $353(73,5)$ & 0,000 \\
\hline $\begin{array}{l}\text { Q2. Most common source of infection associated with infections } \\
\text { (Germs already present on or within the patient) }\end{array}$ & $48(15,2)$ & $25(15,2)$ & $73(15,2)$ & 0,155 \\
\hline \multicolumn{5}{|c|}{ Q3.Which of the following statements on alcohol-based handrub and handwashing with soap and water are true? } \\
\hline $\begin{array}{l}\text { Handrubbing is more rapid for hand cleansing than handwashing } \\
\text { (TRUE) }\end{array}$ & $210(66,7)$ & $160(97,0)$ & $370(77,1)$ & 0,000 \\
\hline Washing the hand causes more dryness (FALSE) & $117(37,1)$ & $51(30,9)$ & $168(35,0)$ & 0,000 \\
\hline Handrubbing is more effective against germs than handwashing (FALSE) & $151(47,9)$ & $15(9,1)$ & $166(34,6)$ & 0,000 \\
\hline Hand washing and hand rub should be done alternately (FALSE) & $190(60,3)$ & $75(45,5)$ & $265(69,7)$ & 0,035 \\
\hline $\begin{array}{l}\text { How long is enough time for alcohol-based hand sanitizer to kill germs? } \\
\text { ( } 20 \text { seconds) }\end{array}$ & $92(29,2)$ & $31(18,8)$ & $123(25,6)$ & 0,001 \\
\hline \multicolumn{5}{|c|}{ Q4. Which type of hand hygiene method is required in the following situations? } \\
\hline Before palpation of the abdomen (rubbing) & $165(52,4)$ & $103(62,4)$ & $268(55,8)$ & 0,035 \\
\hline Before giving an injection (rubbing) & $128(40,6)$ & $113(68,5)$ & $241(50,2)$ & 0,000 \\
\hline After emptying a bedpan (washing) & $235(74,6)$ & $81(49,1)$ & $316(65,8)$ & 0,000 \\
\hline After removing examination gloves (rubbing) & $172(54,6)$ & $76(46,1)$ & $248(51,6)$ & 0,786 \\
\hline After making a patient's bed (rubbing) & $189(60,0)$ & $53(32.1)$ & $242(50,4)$ & 0,000 \\
\hline After visible exposure to blood (washing) & $222(70,5)$ & $66(40.0)$ & $288(60.0)$ & 0,000 \\
\hline \multicolumn{5}{|c|}{ Q5. Which of the following should be avoided, as associated with increased likelihood of colonisation of hands with harmful germs } \\
\hline Wearing jewellery (YES) & $289(97,1)$ & $147(89,1)$ & $436(90,8)$ & 0,338 \\
\hline Damaged skin (YES) & $288(91,4)$ & $149(90,3)$ & $437(91,0)$ & 0,682 \\
\hline Artificial fingernails (YES) & $297(94,3)$ & $153(92,7)$ & $450(93,8)$ & 0,503 \\
\hline Regular use of a hand cream (NO) & $227(72,1)$ & $106(64,2)$ & $333(69,4)$ & 0,077 \\
\hline
\end{tabular}

\begin{tabular}{|c|c|c|c|c|}
\hline Attitudes and behaviors & $\begin{array}{l}\text { Nursing } \\
(\mathrm{n}=315)\end{array}$ & $\begin{array}{l}\text { Elderly care / anesthesia } \\
\qquad(\mathrm{n}=165)\end{array}$ & $\begin{array}{c}\text { Total } \\
(n=480)\end{array}$ & \multirow{2}{*}{$\mathbf{p}$} \\
\hline Compliance hand hygiene during internships & No.(\%) & No.(\%) & No.(\%) & \\
\hline Yes & $285(90,5)$ & $137(83,0)$ & $422(88,0)$ & \multirow{2}{*}{0,017} \\
\hline No & $30(9,5)$ & $28(17,0)$ & $58(12,0)$ & \\
\hline \multicolumn{4}{|l|}{ Frequency of daily hand washing } & \multirow{5}{*}{0,000} \\
\hline$\leq 3$ times & $13(4,2)$ & $16(9,7)$ & $29(6,0)$ & \\
\hline 4-7 times & $93(29,5)$ & $77(46,7)$ & $170(35,5)$ & \\
\hline 8-10 times & $178(56,5)$ & $62(37,6)$ & $240(50,0)$ & \\
\hline Hands when dirty & $31(9,8)$ & $10(6,0)$ & $41(8,5)$ & \\
\hline \multicolumn{4}{|l|}{ Material use for hand hygiene } & \multirow{3}{*}{0,188} \\
\hline Water and soap & $305(96,8)$ & $164(99,4)$ & $469(97,7)$ & \\
\hline Alcohol-based handrub & $10(3,2)$ & $1(0,6)$ & $11(2,3)$ & \\
\hline \multicolumn{4}{|l|}{ Drying material for hands } & \multirow{4}{*}{0,007} \\
\hline Paper towels & $167(53,0)$ & $63(38,2)$ & $230(47,9)$ & \\
\hline Fabric towel & $132(41,9)$ & $88(53,3)$ & $220(45,8)$ & \\
\hline Wipe hands to the clothes & $16(5,1)$ & $14(8,5)$ & $30(6,3)$ & \\
\hline
\end{tabular}


In general, nursing students had more knowledge about effects of alcohol-based handrub and handwashing as well as methods for necessary situations. However it was not desired level in generally (Table 1). Our study was consistent with Indian and Nepal studies $(20,22,24)$.

Only a quarter of all students knew the minimum effect of alcohol-based hand disinfectants on microorganisms (Table 1). This finding was similar to a study conducted in India (\%35) and Nepal (\%24) where minörity of the participants didn't know the minimum time required for hundrubbing (20). Contrary to our study, this rate was found to be $90 \%$ among nurses in Saudi Arabia (25).

In low and middle-income countries it was noteworthy that all health workers had insufficient knowledge and behavior. Studies conducted with Polish physicians and medical students (26), Iranian nurses and nurse assistants (27), Serbian doctor and auxiliary health personnel (28) were important evidence in this accordance. According to the World Bank income classification 2018 (29), Turkey was in the group of middle-high income countries and studies performed in our country knowledge and behavior of health workers were low (30).
In the present study hand hygiene behaviors were found to be very low especially among students training in elderly care/anesthesia departments (Table 2). This result overlapped with Table 1. Nursing students had more knowledge compared to elderly care/anesthesia students, This may be due to hand hygiene course in their curriculum. Nurses students also spend more time in the wards and have more chance of practicing hand hygiene.

One of the main obstacles for HCWs is hand hygiene compliance among health workers. Evidence suggested that poor hand hygiene compliance in health-care facilities an important aspects of low knowledge and poor behaviors. In worldwide average compliance was reported as $38,7 \%$ (1). On the other hand, a majority of students (\%88) were self-reported compliance but this result was not compatiple with low knowledge and poor behaviors (Table 2).

In our study, it was a pleasing result that participants aware of the situations to be avoided in patient care which was compatible with other studies $(20,22)$.

In present study, hand hygiene behaviors of female students were higher than male students (Table 3).

\begin{tabular}{|c|c|c|c|c|}
\hline \multirow[b]{2}{*}{ Behaviors } & \multicolumn{2}{|c|}{ Gender } & \multirow[b]{2}{*}{$\begin{array}{c}\text { Total } \\
(n=480)\end{array}$} & \multirow{3}{*}{$\mathbf{p}$} \\
\hline & $\begin{array}{l}\text { Women } \\
(n=342)\end{array}$ & $\begin{array}{c}\text { Men } \\
(n=138)\end{array}$ & & \\
\hline Frequency of daily hand washing & No. (\%) & No. (\%) & No. (\%) & \\
\hline$\leq 3$ times & $13(3,8)$ & $16(11,6)$ & $29(6,0)$ & \multirow{4}{*}{0,001} \\
\hline 4-7 times & $128(37,4)$ & $42(30,4)$ & $170(35,4)$ & \\
\hline 8-10 times & $178(52,0)$ & $62(44,9)$ & $240(50,0)$ & \\
\hline Hands when dirty & $23(6,7)$ & $18(13,0)$ & $41(8,6)$ & \\
\hline \multicolumn{5}{|l|}{ Material use for hand hygiene } \\
\hline Water and soap & $336(98,2)$ & $133(96,4)$ & $469(97,7)$ & \multirow{2}{*}{0,023} \\
\hline Alcohol-based handrub & $6(1,8)$ & $5(3,6)$ & $11(2,3)$ & \\
\hline \multicolumn{5}{|l|}{ Drying material for hands } \\
\hline Paper towels & $172(50,3)$ & $58(42,0)$ & $230(48,0)$ & \multirow{3}{*}{0,000} \\
\hline Fabric towel & $159(46,5)$ & $61(44,2)$ & $220(45,8)$ & \\
\hline Wipe hands to the clothes & $11(3,2)$ & $19(13,8)$ & $30(6,2)$ & \\
\hline
\end{tabular}




\begin{tabular}{|c|c|c|c|c|c|}
\hline \multirow[b]{2}{*}{ Behaviors } & \multicolumn{3}{|c|}{ Region } & \multirow[b]{2}{*}{$\begin{array}{c}\text { Total } \\
(n=480)\end{array}$} & \multirow{3}{*}{$\mathbf{p}$} \\
\hline & $\begin{array}{c}\text { West/North } \\
(n=217)\end{array}$ & $\begin{array}{c}\text { İnner/Middle } \\
(n=142)\end{array}$ & $\begin{array}{l}\text { South/east/ } \\
\text { South-east } \\
(n=121)\end{array}$ & & \\
\hline Frequency of daily hand washing & No. (\%) & No. (\%) & No. (\%) & No. (\%) & \\
\hline$\leq 3$ times & $10(4,6)$ & $14(9,9)$ & $5(4,1)$ & $29(6,0)$ & \multirow{4}{*}{0,010} \\
\hline 4-7 times & $62(28,6)$ & $61(43,0)$ & $47(38,8)$ & $170(35,4)$ & \\
\hline 8-10 times & $126(58,1)$ & $56(39,4)$ & $58(47,9)$ & $240(50,0)$ & \\
\hline Hands when dirty & $19(8,8)$ & $11(7,7)$ & $11(9,1)$ & $41(8,6)$ & \\
\hline \multicolumn{6}{|l|}{ Material use for hand hygiene } \\
\hline Water and soap & $212(97,7)$ & $140(98,6)$ & $117(96,7)$ & $469(97,7)$ & \multirow{2}{*}{0,413} \\
\hline Alcohol-based handrub & $5(2,3)$ & $2(1,4)$ & $4(3,3)$ & $11(2,3)$ & \\
\hline \multicolumn{6}{|l|}{ Drying material for hands } \\
\hline Paper towels & $125(57,6)$ & $58(40,8)$ & $47(38,8)$ & $230(48,0)$ & \multirow{3}{*}{0,001} \\
\hline Fabric towel & $80(36,9)$ & $78(54,9)$ & $62(51,2)$ & $220(45,8)$ & \\
\hline Wipe hands to the clothes & $12(5,5)$ & $6(4,2)$ & $12(9,9)$ & $30(6,2)$ & \\
\hline
\end{tabular}

Hand hygiene behaviors were better among students whose family residing in the western/ northern region of the country (Table 4). This may be due to the different cultural characteristics and habits of the regions.

\section{CONCLUSION}

In our study showed that there was a big gap on hand hygiene knowledge, attitude and behaviors among two health related departments. Gender and residence region were effective on hand hygiene behaviors. Through continuous pre and post-graduate programs students' knowledge and practice on hygiene should be updated which were training in health departments. Programs supported by practical laboratory sessions can be a foundation stone in this respect.

\section{Acknowledgement}

None

\section{Conflict of Interest}

None

\section{REFERENCES}

1. World Health Organization. World Health Organization guidelines on hand hygiene in health care, 2009. Available at http://apps.who. int/iris/ bitstream/10665/44102/ 1/9789241597906_eng.pdf.

2. WHO. Report on the burden of endemic health care-associated infection worldwide, $2011 . \quad$ http://whqlibdoc.who.int/ publications/2011/9789241501507_eng.pdf.

3. Allegranzi B, Nejad SB, Combescure C, et al. Burden of endemic health care-associated infection in developing countries: systematic review and meta-analysis. Lancet 2011; 377: 228-41.

4. European Centre for Disease Prevention and Control (ECDC). https:// ecdc.europa.eu/en/home.

5. Centers for Disease Control and Prevention (CDC). https://www.cdc. gov/handhygiene/science/index.html

6. Dumpis U, Balode A, Vigante D, Narbute I, Valinteliene R, Pïrags V, et al. Prevalence of nosocomial infections in two Latvian hospitals. Eurosurveillance 2003, 8:73-78.

7. Azzam R, Dramaix M. A one-day prevalence survey of hospitalacquired infections in Lebanon. Journal of Hospital Infection 2001; 49:74-78.

8. Metintas S, Akgun Y, Durmaz G, Kalyoncu C. Prevalence and characteristics of nosocomial infections in a Turkish university hospital. American Journal of Infection Control 2004; 32: 409-413.

9. Hughes AJ, Ariffin N, Huat TL, Abdul Molok H, Hashim S, Sarijo J, et al. Prevalence of nosocomial infection and antibiotic use at a university medical center in Malaysia. Infection Control and Hospital Epidemiology 2005; 26:100-104.

10. Gosling R1, Mbatia R, Savage A, Mulligan JA, Reyburn H. Prevalence of hospital-acquired infections in a tertiary referral hospital in northern Tanzania. Annals of Tropical Medicine and Parasitology 2003; 97:69-73.

11. Kallel $H$, Bahoul $M$, Ksibi $H$, Dammak $H$, Chelly $H$, Hamida $C B$, et al. Prevalence of hospital-acquired infection in a Tunisian hospital. Journal of Hospital Infection 2005; 59:343-347. 
12. Jroundi I, Khoudri I, Azzouzi A, Zeggwagh AA, Benbrahim NF, Hassouni $F$, et al. Prevalence of hospital-acquired infection in a Moroccan university hospital. American Journal of Infection Control 2007; 35:412-416.

13. Faria S, Sodano L, Gjata A, Dauri M, Sabato AF, Bilaj A, et al. The first prevalence survey of nosocomial infections in the University Hospital Centre'Mother Teresa' of Tirana, Albania. Journal of Hospital Infection 2007; 65:244-250.

14. T.C. Sağlık Bakanlığı. https://www.saglik.gov.tr/TR,50623/saglikhizmeti-iliskili-enfeksiyonlarin-onlenmesi-sozlesmesi-imzalandi. html.

15. Pittet D, Allegranzi B, Sax H, Dharan S, Pessoa-Silva CL, Donaldson $L$, et al. Evidence-based model for hand transmission during patient care and the role of improved practices. Lancet Infect Dis 2006; 6: 641-52;

16. Pincock T, Bernstein P, Warthman S, Holst E. Bundling hand hygiene interventions and measurement to decrease health care-associated infections. Am J Infect Control 2012; 40 (suppl 1): S18-27;

17. Allegranzi B, Pittet D. The role of hand hygiene in healthcareassociated infection prevention. J Hosp Infect 2009; 73: 305-15.

18. Erasmus V, Daha TJ, Brug H, Richardus JH, Behrendt MD, Vos MC, et al. Systematic review of studies on compliance with hand hygiene guidelines in hospital care. Infect Control Hosp Epidemiol 2010; 31: 283-94.

19. Trampuz A, Widmer AF. Hand hygiene: a frequently missed lifesaving opportunity during patient care. Mayo Clin Proc 2004;79(1):109-16.

20. Paudel IS, Ghosh V, Adhikari P. Knowledge, Attitude and Practice of nursing students regarding hand hygiene in Western region of Nepal. JCMS Nepal 2016;12(4):169-73.

21. Ariyarathne M, Gunasekara T, Weerasekara MM, Kottahachchi J, Kudavidanage BP, Fernando SSN. Knowledge, attitudes and practices of hand hygiene among final year medical and nursing students at the University of Sri Jayewardenepura. Sri Lankan Journal of Infectious Diseases 2013; 3(1):

22. Manasa K, Chandrakumar SG, Prashantha B. Assessment of hand hygiene knowledge among medical and nursing students of Mysore medical college and research institute, Mysore. Int J Community Med Public Health 2018;5(3):1133-1137.

23. Arthi E, Abarna V, Bagyalakshmi R, Anitharaj M, Vijayasree S. Assessment of knowledge, attitude and practice of hand hygiene among nursing and medical students in a tertiary care hospital in Puducherry, India. Int J Contemporary Med Res 2016;3(4):1203.

24. Nair SS, Hanumantappa R, Hiremath SG, Siraj MA, Raghunath P. Knowledge, attitude, and practice of hand hygiene among medical and nursing students at a tertiary health care centre in Raichur, India. ISRN Prevent Med. 2014.

25. Aledeilah RDI, Abo el-Fetoh NM, Albaker AF, Aljabbab AA, Alkhannani AJ, Alkhannani SJ, et al. Assessment of Knowledge, Attitude and Practice of Hand Hygiene among Health Care Workers in Arar City, Saudi Arabia. The Egyptian Journal of Hospital Medicine 2018;70 (3):491-498.

26. Wałaszek M, Kołpa M, Wolak Z, Rózanska A, Mach JW. Poor Hand Hygiene Procedure Compliance among Polish Medical Students and Physicians-The Result of an Ineffective Education Basis or the Impact of Organizational Culture? Int J Environ Res Public Health 2017; 14: 1026.

27. Zakeri H, Ahmadi F, Rafeemanesh E, Saleh LA. The knowledge of hand hygiene among the healthcare workers of two teaching hospitals in Mashhad. Electron Physician 2017; 9(8): 5159-5165.

28. Rajcevic S, Duric D, Grujičić M, Dugandzija T. Knowledge, habits and attitudes of health care workers about hand hygiene. Healthmed 6(4):1018-1023.

29. World Bank Country Classifications, 2018. https://datahelpdesk. worldbank.org/ knowledgebase/articles/906519.
30. Kaya Ş, Kaçmaz Z, Çetinkaya N, Kaya Ş, Temiz H, Inalcan M. Assessment of Knowledge and Behavior on Hand Hygiene in Health Care Workers. Erciyes Med J 2015; 37(1): 26-30. 